\title{
Farm Income Variability and the Supply of Off-Farm Labor by Limited-Resource Farmers
}

\author{
Oscar Vergara, Keith H. Coble, George F. Patrick, \\ Thomas O. Knight, and Alan E. Baquet
}

\begin{abstract}
We study the relationship between the off-farm labor decision and the limited-resource farmers' and spouses' off-farm wages, experience, education, and sources of income. We found that farmers' and spouses' off-farm experience and wages are significant factors in explaining the off-farm labor supply decision. Contrary to expectations, farm income variability is not significant in the farmers' and spouses' decision to seek off-farm work. The off-farm labor supply of farmers and their spouses is negatively correlated with income transfers from the government. It was also found that the spouse is a residual supplier of on-farm and off-farm labor.
\end{abstract}

Key Words: farm income variability, limited-resource farmer, off-farm work, Tobit regression

JEL Classifications: C34, D19, D81, J15, J22, Q18

Improvement of economic and social conditions in the poorer areas of rural America is a central concern of the U.S. Department of Agriculture (USDA; Swanson). Title XXV of the Food, Agriculture, Conservation, and Trade Act of 1990 states that the Secretary of Agriculture will provide outreach and technical

Oscar Vergara is postdoctoral research associate and Keith $\mathrm{H}$. Coble is associate professor, Department of Agricultural Economics, Mississippi State University, Mississippi State, MS. George F. Patrick is professor, Department of Agricultural Economics, Purdue University, West Lafayette, IN. Thomas $O$. Knight is professor, Department of Agricultural and Applied Economics, Texas Tech University, Lubbock, TX. Alan E. Baquet is professor, Department of Agricultural Economics, University of Nebraska, Lincoln, NE.

The authors thank two anonymous reviewers of the Journal for their useful comments and insights. This research was supported in part by the USDA Risk Management Agency, but the views expressed in this paper are not necessarily endorsed by the sponsoring agency. assistance to encourage and assist socially disadvantaged farmers and ranchers to own and operate farms and ranches and to participate in agricultural programs. This assistance will include information on application and bidding procedures, farm management, and other essential information to participate in agricultural programs. More recently, the needs of limited-resource farmers were again recognized in the Agricultural Risk Protection Act of 2000. This Act mandated that the USDA increase its efforts to provide risk management tools and risk management education for limited-resource minority farmers and ranchers.

Despite a steady decline in number since 1945 , farms with $\$ 250,000$ in gross sales or less remain important contributors to rural economies and U.S. agriculture (Perry et al.). These farms, which are referred to as small farms by the National Commission on Small Farms (USDA), constitute $90 \%$ of all U.S. 
farms, own $67 \%$ of the farmland, and hold $77 \%$ of the farm sector's net worth. They also contribute significantly to rural economies as purchasers of inputs and supplies and as preservers of the rural landscape (Mishra, ElOsta, and Steele). According to the typology of U.S. farms, limited-resource farms are included in the small farms category (Hoppe). As with the rest of small farms, limited-resource households are also important for the rural economy of their communities.

Traditionally, operators of commercialsized farms rely on production and marketing contracts, vertical integration, futures contracts and hedging, financial reserves, and crop insurance as means to manage farm risk (Harwood et al.). Nevertheless, risk management tools available to limited-resource farmers are constrained by farm and nonfarm factors. According to Dismukes, Harwood, and Hoppe, the use of crop insurance as a risk management tool by limited-resource farmers is minimal because there is no crop insurance for most of the crops they grow. Furthermore, small acreages in row crops reduce the likelihood of participation in the use of marketing contracts and the use of futures and options contracts. For example, small acreages would limit the ability of a producer to meet minimum futures contract size. Vergara et al. found that only $16 \%$ of the farmers used crop insurance, whereas $56 \%$ worked off-farm. Therefore, off-farm income seems an important aspect of how limited-resource farmers manage risk. Wages and salaries are important sources of this off-farm income, but other sources such as Social Security are also leading sources of off-farm income for limited-resource farm operator households. This is not surprising given the high proportion of limited-resource farmers who are more than 65 years old (Dismukes, Harwood, and Bentley).

The increased reliance on off-farm income by commercial farm operators has been well documented in the literature (Corsi and Findeis; Goodwin and Holt; Huffman; Huffman and El-Osta; Huffman and Lange; Lass and Gempesaw; Mishra and Goodwin; Mishra et al.; Mishra and Sandretto; Schultz; Sumner; Tokle and Huffman). Nevertheless, very little is known with respect to the limited-resource farm operator supply of off-farm work. This study aims at increasing the current knowledge on the role that farm income variability and other important economic variables play in the off-farm labor supply decision of limited-resource farmers.

\section{Literature Review}

The farm typology developed by the USDA Economic Research Service (ERS) between 1997 and 1998 categorizes farms into homogeneous groups, based primarily on annual sales and occupation of the operators. The first group identified by the typology is the small family farm. Limited-resource farms lie within this group. Limited-resource farms are family farms with gross sales less than $\$ 100,000$, farm assets less than $\$ 150,000$, and farm operator household income less than $\$ 20,000$ per year. All three conditions must be met in order for a small family farm to be classified under the limited-resource farm category. Unlike other types of farms belonging to the small family farm group, limited-resource farm operators are not restricted to one major occupation. Limited-resource farmers can report farming, a nonfarm occupation, or retirement as their major occupation. The limited-resource farm definition includes farmers with low sales, income, and assets, regardless of their major occupation (Hoppe).

According to USDA-ERS Agricultural Resource Management Study data, there were 150,268 limited-resource farms in the United States in 1998. Most limited-resource farm operator households are located in the South, specifically the USDA farm production regions of Appalachia, Delta States, Southeast, Southern Plains, Delaware, and Maryland (Dismukes, Harwood, and Hoppe).

The circumstances of African American limited-resource farmers are especially striking (Beale). The number of African American-operated farms in the United States has declined dramatically from 925,708 farms in 1920 to 18,451 farms in 1997. Even though the number of farms operated by Caucasians has declined in the same period (from 
$5,498,454$ in 1920 to $1,864,201$ in 1997), the rate of decline has been less severe (Reynolds). Nevertheless, the African American share of the farm operator's population in the South is considerable: $9 \%$ in South Carolina, $8 \%$ in Mississippi, and $4 \%$ in Alabama and Louisiana. Thirty-six percent of African American operators are at least 65 years old, and there are relatively few young African American operators. Around $90 \%$ of African American-operated farms had sales less than $\$ 25,000$ in 1997. African American-operated farms tend to be small-130 acres on average. They are less likely to harvest commodity crops. On the other hand, vegetables such as greens, cabbage, squash, okra, sweet corn, and watermelon are common. A few surveys have been conducted to quantify the training needs of limited-resource minority farmers in areas such as crop insurance and other risk management tools (Dismukes, Harwood, and Bentley).

Several studies examining off-farm work participation of farm households have investigated the factors that influence the off-farm work decision of farm families (Corsi and Findeis; Goodwin and Holt; Huffman; Huffman and El-Osta; Huffman and Lange; Lass and Gempesaw; Mishra and Goodwin; Mishra et al.; Mishra and Holthausen; Mishra and Sandretto; Schultz; Sumner; Tokle and Huffman). Shultz pointed out that off-farm employment is an important means by which farmers and their spouses attempt to reduce the variance of total income.

In an econometric analysis of Illinois farmers' off-farm labor supply, Sumner found that the off-farm wage depends on the farmers' human capital and the local labor market. He found that education significantly increased the probability of farm operators seeking offfarm work. On the other hand, other sources of income and farming experience significantly reduced the probability of farm operators seeking off-farm work.

With the use of household survey data, Tokle and Huffman found that geographical differences have an effect on the off-farm labor participation decisions of farmers and their spouses. Education, race, and off-farm wage positively affected the probability of farm operators seeking off-farm work, and education and race positively affected the probability of the spouse seeking off-farm work.

In an econometric analysis of Pennsylvania farm households, Lass and Gempesaw found that the probability of off-farm employment was affected significantly by the operator's age, spouse's age, spouse's education, farm sales, and other sources of income.

In an econometric analysis of Kansas farmers' off-farm labor supply, Mishra and Goodwin pointed out that commercial farmers reported the primary reason they worked off-farm was the variability, risk, and uncertainty associated with their farm income. That study showed a positive relationship between the coefficient of variation for farm income and off-farm work. The farmer's number of years of off-farm work experience and debtto-asset ratio also positively influenced the probability of farm operators seeking off-farm work. On the other hand, farm experience, total acres, government payments, cropping efficiency, and educational seminars negatively affected the probability of farm operators seeking off-farm work. The spouse's number of years of off-farm experience, debt-to-asset ratio, and educational seminars positively affected the probability of the spouse seeking off-farm work. On the other hand, farm experience, government payments, and children negatively affected the probability of the spouse seeking off-farm work.

More recent studies have focused on the role of farm income variability and its relationship with off-farm labor. In a recent publication, Mishra and Sandretto discussed in detail the important role of off-farm employment in stabilizing the income of farm operators. They showed that farm household income variability remains an issue today and is rising, thus increasing the importance of off-farm work as a farm income-stabilizing agent.

Another recent empirical analysis of Kansas and North Carolina farms conducted by Mishra and Holthausen showed that there is greater off-farm labor force participation as the variability of farm income increases and as the variability of off-farm wages decreases. 
Age and the average hourly wage were also found to positively influence the probability of off-farm work. On the other hand, farm experience, land tenure, and other sources of income negatively influenced the probability of off-farm work.

Even though these recent studies have addressed the role of farm income variability and its relationship with off-farm labor for commercial farm operators, little is known about limited-resource farmers' off-farm labor supply decisions under risk and income variability. The principal contribution of this study is that it is the first econometric study that explores limited-resource farmers' supply of offfarm labor. By bringing together the literature on limited-resource producers and the vein of literature addressing off-farm labor, this analysis sheds light on the role that farm income variability and other important economic variables play in the off-farm labor supply decision of limited-resource farmers. By examining factors that characterize the economic context of the producers, we provide insights into the origins of particular off-farm labor preferences. A better understanding of the perceptions of limited-resource farmers and the underlying causes of off-farm labor supply should contribute to a more informed dialogue with respect to the formulation of future farm policy.

\section{Off-Farm Labor Supply Model}

The off-farm labor supply model used for this study follows the model developed by Mishra and Goodwin. The optimal time allocation by married farm couples between leisure, offfarm work, and on-farm work is given by the maximization of expected utility assuming a Von Neumann-Morgenstern utility function subject to production and time constraints. The maximization problem can be written as

$$
\operatorname{Max} E[U]=E\left[U\left(\pi, L_{\mathrm{F}}, L_{\mathrm{S}}\right)\right]
$$

where $\pi$ represents household income and $L_{\mathrm{F}}$ and $L_{\mathrm{S}}$ represent the farmer and spouse hours of leisure, respectively.

The profit function is given by

$$
\begin{aligned}
\pi= & P Q\left(Z_{\mathrm{F}}, Z_{\mathrm{S}}, T_{\mathrm{F}}, T_{\mathrm{s}}, M\right) \\
& -C(Q, r)+G+W_{\mathrm{F}} H_{\mathrm{F}}+W_{\mathrm{S}} H_{\mathrm{S}},
\end{aligned}
$$

where $P$ is the price of the farm output; $Q\left({ }^{\circ}\right)$ is the farm production function; $Z_{\mathrm{F}}$ and $Z_{\mathrm{S}}$ represent the farmer and spouse human capital function, respectively; $T_{\mathrm{F}}$ and $T_{\mathrm{S}}$ represent the farmer and spouse time allocated to on-farm work, respectively; $M$ is a vector of farm and household characteristics affecting production; $C$ represents goods and services purchased in the market, $\mathbf{r}$ is a vector of input prices, $G$ is other sources of income; $W_{\mathrm{F}}$ and $W_{\mathrm{S}}$ represent the farmer and spouse hourly wage for offfarm work, respectively; and $H_{\mathrm{F}}$ and $H_{\mathrm{S}}$ represent the farmer and spouse time allocated to off-farm work, respectively.

The household time constraint is given by

(3)

$$
\begin{aligned}
\Lambda & =T_{i}+L_{i}+H_{i} \\
T_{i}, H_{i} & \geq 0 \text { for } i=\text { farmer, spouse. }
\end{aligned}
$$

Following Mishra and Goodwin, uncertainty in farm income is assumed to be normally distributed with mean $\mu$ and variance $\sigma^{2}$. The expected utility function to be maximized can be written as

$$
\begin{aligned}
& \mu Q\left(T_{\mathrm{F}}, T_{\mathrm{S}}, Z_{\mathrm{F}}, Z_{\mathrm{S}}\right)-C(Q, r, M) \\
& +W_{\mathrm{F}} H_{\mathrm{F}}+W_{\mathrm{S}} H_{\mathrm{S}}+G \\
& -\frac{\alpha}{2}\left[Q^{2}\left(T_{\mathrm{F}}, T_{\mathrm{S}}, Z_{\mathrm{F}}, Z_{\mathrm{S}}\right) \sigma_{\mathrm{P}}^{2}\right] .
\end{aligned}
$$

Substituting the household time constraint in Equation (3) for $H_{\mathrm{F}}$ and $H_{\mathrm{S}}$ and solving for the first-order condition yields the following equation:

$$
\text { (5) } \frac{\partial Q}{\partial T_{\mathrm{F}}}\left(\mu-\frac{\partial C}{\partial Q}\right)-W_{\mathrm{F}}-\alpha\left(Q(\cdot) \frac{\partial Q}{\partial T_{\mathrm{F}}} \sigma_{\mathrm{F}}^{2}\right)=0
$$

Two important relationships can be derived from Equation (5). By totally differentiating Equation (5) with respect to $T_{\mathrm{F}}$ and $\sigma_{P}^{2}$, the sign of the following partial derivatives with respect to income variability can be inferred:

(6) $\frac{\partial T_{\mathrm{F}}}{\partial \sigma_{\mathrm{P}}^{2}}<0$, and $\frac{\partial T_{\mathrm{S}}}{\partial \sigma_{\mathrm{P}}^{2}}<0$. 
The negative signs on the partial derivatives imply that as farm income variability increases, both farmer and spouse will reduce their on-farm labor supply and, therefore, will increase their off-farm labor supply accordingly.

It is expected that risk-neutral farmers will divide their labor supply between farm and nonfarm employment opportunities such that expected marginal returns are equal between the alternatives. When expected marginal returns are greater in one employment opportunity, more labor will be devoted to that alternative. On the other hand, if producers are risk averse, and if they perceive the variance of wages (or earnings) to be greater in one occupation than another, they will allocate less time to the more risky endeavor and will be willing to accept lower wages in the less risky alternative.

Mishra and Goodwin made a significant contribution when they showed how farm income variability affects the off-farm work decision of farmers and spouses in an expected utility framework. However, their empirical model could have been enhanced through the inclusion of other important variables, such as observed off-farm wages. A more recent paper by Mishra and Holthausen assumed variability in both net farm income and off-farm wages, thus showing the effect that income and wage variability has on the producers' decision to seek off-farm work.

In this paper, our main contributions are twofold. First, we obtain empirical evidence on the effect of observed off-farm wages on the decision of limited-resource farmers and spouses to seek off-farm work. Second, limited-resource farmers are a significantly different population than the commercial farms that have been investigated in past research. Thus, our analysis provides a strong test of the robustness of previous results.

\section{Econometric Procedure}

Most analyses of labor supply encounter situations in which many operators and spouses are not employed off-farm, thus raising the issue of selectivity or censored samples. A standard approach to deal with censoring is the use of Tobit models. Previous research has suggested that operator off-farm labor decisions are made jointly with those of the spouse (Huffman and Lange; Lass and Gempesaw; Oluwole and Findeis). This implies that the off-farm labor supply of an operator could be influenced by the number of hours worked off the farm by the spouse. Therefore, an empirical model should take into consideration that the off-farm labor supply of the operator and the spouse is jointly determined; thus, simultaneous equation estimators are required. An econometric model is based on Equation (4). It consists of a structural bivariate Tobit model of off-farm labor participation that is fitted to the whole sample. The basic Tobit model can be embedded in a recursive simultaneous equations model (Greene) by:

$$
\begin{aligned}
Y_{1}^{*} & =X_{1} \beta+\gamma Y_{2}^{*}+\varepsilon_{1}, \text { and } \\
Y_{2}^{*} & =X_{2} \beta+\gamma Y_{1}^{*}+\varepsilon_{2}, \text { and } \\
\text { Correlation }\left[\varepsilon_{1}, \varepsilon_{2}\right] & =\rho_{12} .
\end{aligned}
$$

The expected value of $Y$ and the expression for the covariance matrix is given by

$$
\begin{aligned}
E\left(Y_{1}, \mid Y_{2}, X_{1}, \varepsilon_{2}\right)= & \beta X_{1}+\gamma Y_{2} \\
& +\left(\sigma_{12} / \sigma_{2}^{2}\right) \varepsilon_{2}, \text { and } \\
\text { Covariance }\left[\varepsilon_{1}, \varepsilon_{2}\right]= & \left|\begin{array}{ll}
\sigma_{11} & \sigma_{12} \\
\sigma_{21} & \sigma_{22}
\end{array}\right| .
\end{aligned}
$$

Other computations and retrievable results are the same as for the univariate Tobit model (Greene). Parameter estimates for Tobit models do not directly correspond to changes in the expected value of the dependent variable brought about by changes in the independent variables. McDonald and Moffitt showed that, in the Tobit model, this effect is given by

(9) $\partial E(Y) / \partial X=F(Z)(X \beta / \sigma) \beta$,

where $Z=X \beta / \sigma$ and $F(Z)$ is the cumulative normal distribution function. Greene has observed that the McDonald and Moffitt decomposition is useful in obtaining the marginal ef- 
fects of $Y_{1}^{*}$ independently from $Y_{2}^{*}$, and vice versa.

\section{Data}

The limited-resource farmer survey was conducted in Mississippi during the summer of 2000 . The population of interest was expected to match the three criteria used by USDA-ERS in its definition of a limited-resource operator: 1) gross sales of farm products less than $\$ 100,000$ per year, 2) value of farm assets less than $\$ 150,000$, and 3) farm operator household income less than $\$ 20,000$ per year.

The Mississippi Agricultural Statistics Service (MASS) was contracted to sample and conduct the enumeration process. The survey was structured to capture both minority groups and farmers whose race was classified as Caucasian. Second, the sample frame included those living in counties with less productive soils ("hill" counties) and individuals living in Mississippi delta counties, which tend to be more crop intensive. A sample of six counties, three from the delta and three from the hills, was chosen. Professional enumerators visited and recorded the producers' answers to a survey instrument.

One hundred percent of the farmers interviewed had a gross value of sales of farm products less than $\$ 100,000$ per year. Ninetythree percent of the farmers interviewed had a value of farm assets less than $\$ 150,000$. Eighty-two percent of the farmers interviewed had a total household income from farm and off-farm sources less than $\$ 20,000$ per year.

Even though our final working sample is a close approximation of the official definition of a limited-resource household, our measure of total household income remains a problem. As defined in our survey, total household income included gross cash income from the farm plus off-farm income. Nevertheless, when measuring the economic well-being of rural families, a net measure of income is generally preferred.

Unfortunately, net income from farming was not available because our survey instrument did not collect information on expenses. Because all the observations met one criterion and the majority of observations met two criteria or more, we relaxed the official limitedresource farm definition to require that only one condition be met (i.e., sales of farm products less than $\$ 100,000$ per year). Under this relaxation, the final working sample was 127 limited-resource farms, once incomplete surveys, deceased farmers, or farmers that went out of business were removed.

The summary statistics reported here represent averages that have been expanded with the use of a MASS-constructed weight variable. This variable maintains consistency between the reported summary statistics and the known population characteristics.

Table 1 provides a description of the variables involved in this study, and Table 2 provides summary statistics on the dependent and independent variables. The empirical model related the total number of hours worked offfarm per week by the operator and the spouse to observable farm and household characteristics. The first dependent variable is farmer hours of off-farm labor. Fifty-six percent of the farmers indicated that they work off-farm. Those who worked off-farm averaged 23 hours per week. The second dependent variable is spouse hours of off-farm labor. Fortyfive percent of the spouses indicated that they also work off-farm. Those who worked offfarm averaged 16 hours per week. The high percentage of non-off-farm labor participation indicates that the choice of an econometric model that takes into consideration censoring in the dependent variables is appropriate.

The remaining variables in Table 1 are independent explanatory variables included in the analysis. The first six variables (Delta County, total acres, farm income variability, participation in USDA programs, farm assets, and race) are measures of the household characteristics [ $M$ in Equation (4)]. Delta County indicates whether the farm is located in any of the Mississippi Delta counties surveyed. Regional variables have been used in past studies (Tokle and Huffman). It is expected that, because of the crop agricultural activity in those counties, farmers and their spouses would tend to work more on-farm than elsewhere. Fifty- 
Table 1. Limited-Resource Farmers' and Spouses' Off-Farm Labor Supply: Description of Variables

\begin{tabular}{|c|c|}
\hline Variable & Description \\
\hline \multicolumn{2}{|l|}{ Dependent Variables } \\
\hline Farmer Off-Farm Hours & $\begin{array}{l}\text { Average hours per week that the operator works off- } \\
\text { farm (hours). }\end{array}$ \\
\hline Spouse Off-Farm Hours & $\begin{array}{l}\text { Average hours per week that the spouse works off- } \\
\text { farm (hours). }\end{array}$ \\
\hline \multicolumn{2}{|l|}{ Independent Variables } \\
\hline Delta County & $\begin{array}{l}\text { Dummy variable }=1 \text { if farm is located in a Missis- } \\
\text { sippi Delta county. }\end{array}$ \\
\hline Total Acres & Total acres in the farm operation (acres). \\
\hline Farm Income Variability & $\begin{array}{l}\text { Dummy variable }=1 \text { if gross income was below or } \\
\text { above the average income of the previous } 5 \text { years. }\end{array}$ \\
\hline Participation in USDA Programs & $\begin{array}{l}\text { Dummy variable }=1 \text { if farmer has participated in } \\
\text { any USDA commodity programs in the past } 5 \\
\text { years. }\end{array}$ \\
\hline Farm Assets & $\begin{array}{l}\text { Dummy variable }=1 \text { if farm asset value is greater } \\
\text { than } \$ 50,000 .\end{array}$ \\
\hline Race & Dummy variable $=1$ if farmer is Caucasian. \\
\hline $\begin{array}{l}\text { Income from non-USDA Government } \\
\text { Sources }\end{array}$ & $\begin{array}{l}\text { Percent of household's gross income from non- } \\
\text { USDA government sources, such as pensions, So- } \\
\text { cial Security, etc. }(\%) \text {. }\end{array}$ \\
\hline Income from Livestock Production & $\begin{array}{l}\text { Percent of household's gross income from livestock } \\
\text { production }(\%) \text {. }\end{array}$ \\
\hline Experience & Operator's years of farming experience (years). \\
\hline Education & $\begin{array}{l}\text { Dummy variable }=1 \text { if farmer obtained a high } \\
\text { school diploma. }\end{array}$ \\
\hline Farmer Off-Farm Wage Rate & $\begin{array}{l}\text { Operator's observed off-farm labor wage rate (dol- } \\
\text { lars/hour). }\end{array}$ \\
\hline Spouse Off-Farm Wage Rate & $\begin{array}{l}\text { Spouse's observed off-farm labor wage rate (dollars/ } \\
\text { hour). }\end{array}$ \\
\hline
\end{tabular}

six percent of the farms in the sample were located in the Delta counties.

The total acres variable measures the total amount of acres available for farming. Sumner, Lass and Gempesaw, and Mishra and Goodwin used this variable in a previous study. On average, the limited-resource farmers in our sample had 145 acres of farmland. It is expected that increased farmland would be correlated with increased amounts of farmers' on-farm work, thus reducing the time available for off-farm labor.

Farm income variability is measured as the variation below or above the average farm income from the previous 5 years. In previous studies, Mishra and Goodwin measured the coefficient of variation of gross farm income, whereas Mishra and Holthausen measured the coefficient of variation of net farm income. It is expected that limited-resource farmers who perceive a downturn in farm income will tend to seek off-farm work as a means to stabilize income. Sixty-five percent of the farmers perceived a downturn in farm income.

Participation in USDA programs measures farmers' past participation in farm programs. It takes a value of one if the farmer has participated in any USDA commodity programs in the past 5 years. This variable has not been used in previous studies. Nevertheless, on the 
Table 2. Limited-Resource Farmers' and Spouses' Off-Farm Labor Supply: Summary Statistics

\begin{tabular}{|c|c|c|c|c|}
\hline Variable & Mean & $\begin{array}{l}\text { Standard } \\
\text { Deviation }\end{array}$ & Minimum & Maximum \\
\hline Farmer Off-Farm Hours ${ }^{a}$ & 23.07 & 22.3484 & 0.00 & 60.00 \\
\hline Spouse Off-Farm Hours ${ }^{b}$ & 16.11 & 19.4647 & 0.00 & 50.00 \\
\hline Delta County & 0.56 & 0.4984 & 0.00 & 1.00 \\
\hline Total Acres & 145.82 & 144.3630 & 2.60 & 700.00 \\
\hline Farm Income Variability & 0.65 & 0.4723 & 0.00 & 1.00 \\
\hline USDA Program & 0.15 & 0.4264 & 0.00 & 1.00 \\
\hline Income from non-USDA Government Sources & 0.27 & 0.4094 & 0.00 & 1.00 \\
\hline Income from Livestock & 0.68 & 0.4172 & 0.00 & 1.00 \\
\hline Farm Assets & 0.69 & 0.4252 & 0.00 & 1.00 \\
\hline Experience & 12.02 & 17.1968 & 4.00 & 70.00 \\
\hline Education & 0.45 & 0.4950 & 0.00 & 1.00 \\
\hline Race & 0.74 & 0.5015 & 0.00 & 1.00 \\
\hline Farmer Off-Farm Wage Rate & 12.36 & 7.9201 & 0.00 & 45.00 \\
\hline Spouse Off-Farm Wage Rate & 7.32 & 7.7460 & 0.00 & 35.00 \\
\hline
\end{tabular}

a Fifty-six percent of the farmers in the sample indicated that they work off-farm.

${ }^{b}$ Forty-five percent of the spouses in the sample indicated that they work off-farm.

basis of the description of risk management needs of limited-resource farmers by Dismukes, Harwood, and Bentley, this variable should be included in the econometric study. It is expected that limited-resource farmers who participated less in government programs will be more motivated to work on-farm than those who did not. Fifteen percent of the producers indicated having participated in government programs in the past.

Farm assets take a value of one if the farm assets are in excess of $\$ 50,000$. Previous studies by Mishra, El-Osta, and Steele and Mishra and Goodwin have used the debt-to-assets ratio rather than farm assets as a proxy for wealth. It is expected that farmers with more farm assets will tend to seek less off-farm employment. Sixty-nine percent of the farmers indicated that they belong to the higher asset value group.

A dummy variable for race indicates whether the limited-resource farmer is Caucasian. Tokle and Huffman used a race variable in a previous study. It is expected to reveal any differences in off-farm labor supply with respect to race. Seventy-four percent of the farmers in the sample were Caucasians.

The next two variables, income received from non-USDA government sources and in- come generated from livestock production, are related to other sources of income [ $G$ in Equation (4)]. Lass and Gempesaw and Sumner used a measure of other income in previous studies. Income received from non-USDA government sources measures percentage of gross household income (measured as gross cash income from farming operation plus gross income from family members working off-farm) generated from pensions, social security payments, or other retirement income. It is expected that operators who benefit more from external sources of income will be less interested in off-farm work as a means to reduce income variability. On average, $27 \%$ of the limited-resource households reported income from non-USDA government payments.

Income generated from livestock production measures the percentage of gross household income (measured as gross cash income from farming operation plus gross income from family members working off-farm) generated from livestock production. This variable has not been used in past studies. Nevertheless, on the basis of a study by Dismukes, Harwood, and Hoppe that shows the importance of livestock production for the limitedresource household, this variable should be included in the econometric study. Because of 
the extensive nature of livestock production, it is expected that operators who depend more on livestock production will have additional time available to work off-farm. On average, $68 \%$ of the limited-resource households reported income from livestock production.

The next two variables, farmer's years of farming experience and education, quantify the initial human capital endowment $[Z$ in Equation (4)]. Experience measures years of farming experience. Mishra and Goodwin and Sumner have used this variable in past studies. Because farming experience should be directly related to increased productivity and profitability, it is expected that older, experienced farmers will prefer to work on-farm rather than seek off-farm employment. The average farming experience of the limited-resource farmers in the sample was 12 years.

Education indicates whether the operator has completed at least a high school degree. Tokle and Huffman and Sumner have used this variable in past studies. It is expected that more educated operators have better off-farm work opportunities. Forty-five percent of the farmers indicated having obtained a high school diploma.

The last two variables, farmer's off-farm wage rate and spouse's off-farm wage rate, explain the hourly wage of off-farm work $[W$ in Equation (4)]. Tokle and Huffman have used these variables in a past study. Farmer offfarm wage rate measures the off-farm wage available to the limited-resource operator if he chooses to work off-farm. It is expected that higher wages would be positively correlated with the operator off-farm supply of labor. On average, the off-farm wage observed by the limited-resource farmers was $\$ 12$ per hour.

Spouse off-farm wage rate measures the off-farm wage available to the spouse if he/ she chooses to work off-farm. Again, it is expected that higher wages would be positively correlated with spouse off-farm supply of labor. On average, the off-farm wage observed for the spouse was $\$ 7$ per hour.

\section{Results}

The model results reported in Table 3 indicate that several of the explanatory variables are highly significant in explaining off-farm labor supply decisions of limited-resource farmers and their spouses. Similar to the results of Huffman, Huffman and Lange, Lass and Gempesaw, and Oluwole and Findeis, and in contrast to the results of Mishra and Goodwin, the results suggest that the labor supply decisions of limited-resource farmers and their spouses are jointly determined. The estimated crossequation coefficient of the disturbances (correlation coefficient) in the bivariate Tobit model is 24.307 for the sampled operators and spouses and is significantly different from zero at the $1 \%$ level. Implications of this result are that the random disturbances in limited-resource couples' off-farm work supply decisions are influenced in the same direction and that the wage-work participation decision of married limited-resource farmer couples in Mississippi are not statistically independent. Therefore, the bivariate Tobit result is appropriate. The predicted probability of working off-farm is given by $F(Z)(X \beta / \sigma)$, where $F(Z)$ is the cumulative standard normal distribution, $X \beta$ is a mean vector of the values of the independent variables multiplied by their Tobit coefficient, and $\sigma$ is the standard deviation of the error term. There is a $73 \%$ probability that an average limited-resource operator will seek work off-farm. On the other hand, there is an $83 \%$ probability that an average spouse will seek work off-farm.

Total acres are negatively correlated with farmers' and spouses' off-farm labor supply. The coefficient is significant for the spouse only. This result contrasts with previous studies (Lass and Gempesaw; Mishra and Goodwin; Sumner). Our results suggest that the spouse's on-farm labor increases as acres increase, thus making the spouse a marginal supplier of on-farm labor. In a recent study of limited-resource farmers, Dismukes, Harwood, and Bentley recognized the increasing participation of the spouse on the farm. Many spouses become primary decision-makers later in life, as farmers become older or incapacitated (Effland, Hoppe, and Cook).

Contrary to expectations, farm income variability was not significant in explaining the limited-resource farmer and spouse off-farm 
Table 3. Limited-Resource Farmers' and Spouses' Off-Farm Labor Supply: Bivariate Tobit Model Results

\begin{tabular}{|c|c|c|c|c|}
\hline \multirow[b]{2}{*}{ Variable } & \multicolumn{2}{|c|}{ Farmer } & \multicolumn{2}{|c|}{ Spouse } \\
\hline & $\begin{array}{l}\text { Maximum } \\
\text { Likelihood } \\
\text { Coefficient }\end{array}$ & $\begin{array}{c}\text { Marginal } \\
\text { Effect } \\
\text { Coefficient }\end{array}$ & $\begin{array}{l}\text { Maximum } \\
\text { Likelihood } \\
\text { Coefficient }\end{array}$ & $\begin{array}{c}\text { Marginal } \\
\text { Effect } \\
\text { Coefficient }\end{array}$ \\
\hline Intercept & $\begin{array}{c}15.095 \\
(13.529)\end{array}$ & & $\begin{array}{l}24.451 \\
(9.146)\end{array}$ & \\
\hline Delta County & $\begin{array}{c}-9.135 \\
(7.490)\end{array}$ & -7.125 & $\begin{array}{c}-0.399 \\
(3.656)\end{array}$ & -0.311 \\
\hline Total Acres & $\begin{array}{c}-0.024 \\
(0.027)\end{array}$ & -0.019 & $\begin{array}{c}-0.016 \\
(0.009)\end{array}$ & $-0.012 * * *$ \\
\hline Farm Income Variability & $\begin{array}{c}-1.759 \\
(7.052)\end{array}$ & -1.372 & $\begin{array}{c}-3.163 \\
(2.799)\end{array}$ & -2.467 \\
\hline USDA Program & $\begin{array}{c}23.194 \\
(16.747)\end{array}$ & $18.091^{*}$ & $\begin{array}{c}0.378 \\
(7.710)\end{array}$ & 0.295 \\
\hline $\begin{array}{l}\text { Income from non-USDA } \\
\text { Government Sources }\end{array}$ & $\begin{array}{c}-0.481 \\
(0.125)\end{array}$ & $-0.375^{* * *}$ & $\begin{array}{c}-0.178 \\
(0.054)\end{array}$ & $-0.139 * * *$ \\
\hline Income from Livestock & $\begin{array}{c}0.250 \\
(0.142)\end{array}$ & $0.195 * * *$ & $\begin{array}{c}0.542 \\
(0.083)\end{array}$ & 0.423 \\
\hline Farm Assets & $\begin{array}{c}6.484 \\
(8.892)\end{array}$ & -5.058 & $\begin{array}{r}-0.875 \\
(4.177)\end{array}$ & -0.663 \\
\hline Experience & $\begin{array}{c}-0.453 \\
(0.294)\end{array}$ & $-0.353 *$ & $\begin{array}{c}-0.194 \\
(0.113)\end{array}$ & $-0.151 * * *$ \\
\hline Education & $\begin{array}{c}3.612 \\
(6.796)\end{array}$ & 2.817 & $\begin{array}{c}4.940 \\
(3.028)\end{array}$ & $3.853 * *$ \\
\hline Race & $\begin{array}{c}1.661 \\
(7.337)\end{array}$ & 1.296 & $\begin{array}{c}0.787 \\
(3.934)\end{array}$ & 0.614 \\
\hline Farmer Off-Farm Wage & $\begin{array}{c}1.392 \\
(0.530)\end{array}$ & $1.086 * * *$ & $\begin{array}{c}-0.556 \\
(0.256)\end{array}$ & $-0.434 * * *$ \\
\hline Spouse Off-Farm Wage & $\begin{array}{l}-1.142 \\
(0.526)\end{array}$ & $-0.891^{* *}$ & $\begin{array}{c}1.239 \\
(0.228)\end{array}$ & $0.966 * * *$ \\
\hline $\begin{aligned} \sigma= & 24.307^{* * * *} \\
& (3.366)\end{aligned}$ & & & & \\
\hline
\end{tabular}

Notes: Numbers in parentheses are standard errors. Single, double, and triple asterisks indicate statistical significance at the $\alpha=0.1,0.05$, and 0.01 levels, respectively.

labor supply decision. It seems that the decision to work off-farm is likely to be a response to overall low farm income rather than variations in income. This result is different from those obtained by Mishra and Goodwin and Mishra and Holthausen. Both studies found that, as farm income variability increases, farm families seek additional off-farm employment to reduce the variance in their household income. Nevertheless, Mishra and Goodwin used 10-year income history of farm households to construct a measure of variance in farm income, whereas Mishra and Holthausen used 26-year net farm income data from the
U.S. Department of Commerce. In this study, we elicited a measure of farm income variability from the farmers by asking them to rate their perceived farm income variability below or above the average farm income from the previous 5 years. This measure of farm income variability might have limitations. More research is needed to verify this finding.

Contrary to expectations, past participation in USDA programs is positively associated with farmers' off-farm labor supply. In a question not reported here, limited-resource farmers surveyed in this study indicated that current government programs designed to reduce 
farm risk and income variability are not tailored to meet their specific needs. Therefore, it is not unreasonable to expect that farmers would seek off-farm work as a means to reduce income variability. The results suggest that farmers that had participated in government programs in the past would be expected to work 18 hours more per week off-farm.

Additional income from non-USDA government payments is negatively correlated with farmers' and spouses' off-farm labor supply. This result is consistent with Mishra and Goodwin. The coefficient is significant for both farmer and spouse. It is expected that non-USDA government payments could lessen the need for off-farm labor by providing the farm household with an alternative source of income. The results suggest that a $10 \%$ increase in income from non-USDA government payments decreases the farmers' expected offfarm labor supply by almost 4 hours per week. Similarly, the spouses' expected off-farm labor supply is decreased by almost 1.4 hours per week. This result has important implications for rural policy. Both off-farm work and income transfers contribute to reduced farm income variability and increase the likelihood that limited-resource farmers will remain farming.

Income earned from livestock production is positively correlated with farmers' off-farm labor supply. Because livestock production is often a less labor-intensive activity, the operators would have additional time to seek offfarm work as a means to compensate for low farm income. The results suggest that a $10 \%$ increase in the percentage of income from livestock production increases the farmer's expected off-farm labor supply by almost 2 hours per week.

According to expectations, experience is negatively correlated with farmers' and spouses' off-farm labor supply. This result is consistent with the work of Mishra and Goodwin and Sumner. It is expected that older, experienced farmers and spouses will prefer to work on-farm rather than seek off-farm employment. The results suggest that experienced farmers would reduce their expected supply of off-farm labor by 3.5 hours per week for each additional 10 years of farming experience. Similarly, the spouses' expected off-farm supply of labor is reduced by 1.5 hours per week for each additional 10 years of farming experience.

Years of formal education are positively correlated with farmers' and spouses' off-farm labor supply. This result is consistent with the work of Goodwin and Holt; Mishra and Goodwin; Oluwole and Findeis; Sumner; and Tokle and Huffman. However, the coefficient is significant for the spouse only. This might suggest that a high school diploma increases the probability that the spouse will find off-farm work, thus increasing the amount of off-farm work hours he or she is willing to allocate. The results suggest that spouses who obtained a high school diploma would be expected to work almost 4 hours more per week off-farm.

The farmers' off-farm wage rate is positively correlated with farmers' off-farm labor supply and negatively correlated with the spouse off-farm labor supply. The coefficient is significant for both farmer and spouse. This result implies that as farmers perceive better wages in the labor market, they tend to increase their off-farm labor supply. On the other hand, an increase in the farmers' off-farm wage rate decreases the spouses' off-farm labor supply. According to the results, an hourly wage increase of one dollar increases the farmers' off-farm labor supply by 1 hour per week and decreases the spouses' off-farm labor supply by almost 0.5 hour per week.

The spouses' off-farm wage rate is negatively correlated with the farmers' off-farm labor supply and positively correlated with the spouses' off-farm labor supply. The coefficient is significant for both farmers and spouses. This result implies that as farmers perceive better wages in the labor market for their spouses, they substitute spouses' off-farm labor for farmers' off-farm labor. According to the results, an hourly wage increase for the spouses of 1 dollar decreases the farmers' offfarm labor supply by almost 0.9 hours per week and increases the spouses' off-farm labor supply by almost 1 hour per week. Given the importance of off-farm income for the limited-resource household, programs aimed at 
increasing the human capital of the spouses would have a double positive effect by increasing the expectation of better off-farm wages and, therefore, reducing the likelihood of the farmers seeking off-farm employment.

\section{Conclusions}

This paper examined the determinants of offfarm labor participation decisions of limitedresource farmers and their spouses, focusing on farm income variability. It also attempted to determine whether farm couples jointly make such decisions. This paper contributes to the body of literature directed at understanding the labor supply of farm families, with the additional focus on limited-resource farmers, which is a group of producers that has not received a substantial amount of attention from researchers. Our results showed that farm income variability is not significant in the limited-resource farmer and spouse decision to seek off-farm work. It seems that the decision to work off-farm is likely to be a response to overall low farm income rather than variation in income. Given the importance of farm income variability in the formulation of public policy for agriculture, more research is needed to verify this finding.

This study contributes by pointing out the importance of the economic conditions in the off-farm labor decision of both farmer and spouse. When off-farm wages are high, both farmer and spouse tend to seek additional offfarm work and thus reduce the likelihood of farm income variability. As Mishra and Holthausen point out, changes in the minimum wage laws could have a strong effect on the decision of limited-resource households to work off-farm. Also, off-farm income has played a prominent role in supplementing low net farm returns and contributed to the stability of farm household income and the number of farm residents in recent years. Rural development policies that encourage the development of off-farm employment opportunities could contribute to aid both low-income farm households that leave agriculture and farm households that prefer to pursue dual employment on- and off-farm.
Further research is needed to examine other important factors affecting the off-farm employment decision of limited-resource farmers. Also, there is a greater role for extension education and research programs that address the effect of current risk management programs on the limited-resource household. It is in the best interest of limited-resource farm operators to increase one or more of their household income, assets, or sales to move out of the limited-resource farm category. Given the interest by government agencies to serve their clientele equally and fairly, there is likely to be a continued demand for research that will guide policy in this area.

[Received October 2002; Accepted November 2003.]

\section{References}

Beale, C. "African-American Farmers: Why Such a Severe and Continuing Decline?" Rural Development Perspectives. Washington, DC: U.S. Department of Agriculture, Economic Research Service, February 1991.

Corsi, A., and J. Findeis. "True State Dependence and Heterogeneity in Off-Farm Labor Participation." European Review of Agricultural Economics 27(2000):127-52.

Dismukes, R., J. Harwood, and S. Bentley. "Characteristics and Risk Management Needs of Limited-Resource and Socially Disadvantaged Farmers." Washington, DC: U.S. Department of Agriculture, Economic Research Service, April 1997.

Dismukes, R., J. Harwood, and R. Hoppe. "Limited-Resource Farmers: Their Risk Management Needs." Agricultural Outlook. Washington, DC: U.S. Department of Agriculture, Economic Research Service, May 1997.

Effland, A., R. Hoppe, and P. Cook. "Minority and Women Farmers in the U.S." Agricultural Outlook. Washington, DC: U.S. Department of Agriculture, Economic Research Service, May 1998.

Goodwin, B., and M. Holt. "Parametric and Semi Parametric Modeling of the Off-Farm Labor Supply of Agrarian Households in Transition Bulgaria." American Journal of Agricultural Economics 84(2002):184-209.

Greene, W. Econometric Analysis, 4th ed. Upper Saddle River, NJ: Prentice Hall, 2000.

Harwood, J., R. Heifner, K. Coble, J. Perry, and A. 
Somwaru. "Managing Risk in Farming: Concepts, Research, and Analysis." Washington, DC: U.S. Department of Agriculture, Economic Research Service, Agricultural Economic Report 774, March 1999.

Hoppe, R. "Structural and Financial Characteristics of U.S. Farms: 2001 Family Farm Report." Washington, DC: U.S. Department of Agriculture, Economic Research Service, Agriculture Information Bulletin 768, May 2001.

Huffman, W. "Farm and Off-Farm Work Decisions: The Role of Human Capital." The Review of Economics and Statistics 62(1980):14-23.

Huffman, W., and M. Lange. "Off-Farm Work Decisions of Husbands and Wives: Joint Decision Making." The Review of Economics and Statistics 71(1989):471-80.

Huffman, W., and H. El-Osta. "Off-Farm Work Participation, Off-Farm Labor Supply and OffFarm Labor Demand of U.S. Farm Operators." Department of Economics, Staff Paper 290, Iowa State University, 1997.

Lass, D., and C. Gempesaw. "The Supply of OffFarm Labor: A Random Coefficient Approach." American Journal of Agricultural Economics 74(1992):400-08.

McDonald, J., and R. Moffitt. "The Uses of Tobit Analysis." The Review of Economics and Statistics 62(1980):318-21.

Mishra, A., and B. Goodwin. "Farm Income Variability and the Supply of Off-Farm Labor." American Journal of Agricultural Economics 79(1997):880-87.

Mishra, A., and D. Holthausen. "Effect of Farm Income and Off-Farm Wage Variability on OffFarm Labor Supply." Agricultural and Resource Economics Review 31(2002):187-99.

Mishra, A., H. El-Osta, M. Morehart, J. Johnson, and J. Hopkins. "Income, Wealth, and the Economic Well-Being of Farm Households." Washington, DC: U.S. Department of Agriculture, Economic Research Service, Agricultural Economic Report 812, July 2002.

Mishra, A., H. El-Osta, and C. Steele. "Factors Affecting the Profitability of Limited-Resource and Other Small Farms." Agricultural Finance Review 59(1999):77-91.
Mishra, A., and C. Sandretto. "Stability of Farm Income and the Role of Nonfarm Income in U.S. Agriculture." Review of Agricultural EConomics 24(2002):208-21.

Oluwole, A., and J. Findeis. "An Econometric Analysis of Off-Farm Labor Participation Among U.S. Farm Families, 1977-1998."' Department of Agricultural Economics and Rural Sociology, The Pennsylvania State University, 2001.

Perry, J., R. Hoppe, B. Green, L. Christensen, C. Greene, C. Handy, S. Koenig, C. Dodson, E. Young, C. Steele, and T. Raney. "Small Farms in the U.S." Agricultural Outlook. Washington, DC: U.S. Department of Agriculture, Economic Research Service, May 1998.

Reynolds, B. "Black Farmers in America 18652000: The Pursuit of Independent Farming and the Role of Cooperatives." Washington, DC: U.S. Department of Agriculture, Rural Business Cooperative Service, RBS Research Report 194, October 2002.

Schultz, P. "Estimating Labor Supply Functions for Married Women." Female Labor Supply: Theory and Estimation. J.P. Smith, ed. Princeton, NJ: Princeton University Press, 1980.

Sumner, D. "The Off-Farm Labor Supply of Farmers." American Journal of Agricultural Economics 64(1982):499-509.

Swanson, L. "Racial-Ethnic Minorities in Rural Areas." Washington, DC: U.S. Department of Agriculture, Economic Research Service, April 1995.

Tokle, J., and W. Huffman. "Local Economic Conditions and Wage Labor Decisions of Farm and Rural Non-Farm Couples." American Journal of Agricultural Economics 73(1991):652-70.

U.S. Department of Agriculture. "A Time to Act: A Report of the National Commission on Small Farms." Washington, DC: National Commission on Small Farms, January 1998.

Vergara, O., K. Coble, T. Knight, G. Patrick, and A. Baquet. "Understanding Limited-Resource Farmers' Risk Management Decision Making: Summary and Preliminary Analysis." Department of Agricultural Economics, AEC Research Report 2001-003, Mississippi State University, May 2001. 
* 